OPEN ACCESS

International Journal of Management \& Entrepreneurship Research

P-ISSN: 2664-3588, E-ISSN:2664-3596

Volume 2, Issue 5, P.No. 332-343, October, 2020

Fair East Publishers

Journal Homepage: www.fepbl.com/index.php/ijmer

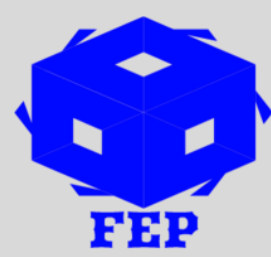

\title{
CHALLENGES OF STUDENT MANAGEMENT INFORMATION SYSTEM (MIS) IN GHANA: A CASE STUDY OF UNIVERSITY FOR DEVELOPMENT STUDIES, WA CAMPUS
}

\author{
Justice Agyei Ampofo ${ }^{1,2}$ \\ ${ }^{1}$ University for Development Studies, Tamale (Ghana) \\ ${ }^{2}$ University of Education, Winneba (Ghana)
}

*Corresponding Author: Justice Agyei Ampofo

Corresponding Author Email: papajusty@gmail.com

Article Received: 13-09-20

Accepted: 27-09-20

Published: $15-10-20$

Licensing Details: Author retains the right of this article. The article is distributed under the terms of the Creative Commons Attribution-NonCommercial 4.0 License (http://www.creativecommons.org/licences/by-nc/4.0/) which permits non-commercial use, reproduction and distribution of the work without further permission provided the original work is attributed as specified on the Journal open access page.

\section{ABSTRACT}

In conformity with Ghana Government's policy towards digital information system ostensibly to promote 'paperless' economy, UDS in 2016 established the Management Information System (MIS). The aim was to seek efficiently and systematically help in records keeping to ensure quality education service delivery of both staff (teaching and non-teaching) and students. However, the system is beset with inconsistencies and frustrations to users of the system. The study delved into the record keeping function to unearth the challenges of MIS in UDS-Wa Campus. The fact of paucity of literature in this area leaves a gap to be filled. The study is qualitative in nature and purposive sampling technique was used to sample forty (40) respondents. They were six (6) administrative staff, fourteen (14) senior and junior lecturers and twenty (20) student leaders. The study revealed that administrators, lectures and students are unable to assess the Management Information System regularly regardless of entering their correct identification numbers and passwords. The study also found out that the web page and database of the Management Information System of UDS (Wa campus), is very slow distorted always. The study also found out that UDS (Wa-campus) does not have a student Management Information System manager but rather depends on the manager at central administration in Tamale campus. The study further revealed that there are limited experts operating UDS (Wa campus) Management Information System as compared to other public Universities of the country. The study recommends that management of UDS (Wa campus) 
should employ Information and Communication Technology experts in the area of Management Information System (MIS) and Computer Engineering to ensure proper functioning of UDS (Wa campus) Management Information System.

Keywords: Student Management Information System (MIS), University for Development Studies, Wa Campus, Ghana.

\section{INTRODUCTION}

In any educational level, Management Information System is essential to the learning and teaching process (Sing, 2005). Many tertiary institutions in Ghana, especially University for Development Studies (UDS), have seen the need for Management Information System (MIS). This is why Ampofo (2019) postulated that Management Information System is essential in quality service delivery especially in education. Student Management Information System (MIS) is used every day in tertiary institutions in Ghana to help in administration activities (Cowling, 2003; Azman, 2009).

Management Information System helps universities to keep records of students both past and present. According to Iwhiwhu (2005) and Arora (2006) Management Information System is a system that employs the information required by institutions management in making operational, tactical and strategic decisions to ensure quality service delivery. According to Pember (2010), students of today have many options available to them, as such factors that enable educational institutions to attract and retain students should be seriously investigated into. There is competition among the tertiary institutions in Ghana to get more students; hence university without an efficient and effective Management Information System stand to lose student population (Pember, 2010: Ampofo, 2019).

UDS is one of the public institution in Ghana, which was established in 1992 by the PNDC Law 279, with the aim of blending academic work with field work through student's participation in community based research popularly known as Third Trimester Field Practical Programme (TTFPP). The University for Development Studies was established in the three northern regions of Ghana to bridge the gap that existed between the southern part of the country and the northern part of the country. The University shifted from manual purchase of admission forms to online. The aim was to ease the problems prospective student faced with the use of manual system. Again, it targeted the elimination of intermediary activities in the admission process and by-passed the snail-pace operational system of Ghana's postal system. This technology feat did not remain with the admission department; other areas like finance, examination results, the registry and etc migrated unto a central MIS. The connectivity of the University for Development Studies MIS is problematic for student and staff. The question one may ask is why Management Information Systems of tertiary institutions are faced with a lot of challenges? Therefore, there is need to know the challenges in order to establish sound data Management Information System practices. This is why this study seeks to identify the challenges of the UDS, Wa campus MIS.

\section{REVIEW OF RELATED LITERATURE}

\section{Management Information Systems of Student's Records}

The proliferation of information calls for its management in organisations. In complex systems, like university the world over, Management Information System of in-house data is cine qua non. In Ghana, authorities of universities use Management Information System to 
help student's access information about their academics and other activities. Palmer (2000) and Shepherd (2003) emphasize on Management Information System as good for accessing academic information of students in tertiary institutions. Johare (2001) and Blake (2014) asserted that school Management Information System is more effective in teaching and learning process. The introduction of Management Information System by tertiary institutions in Ghana especially, UDS, have changed the school management in totality. Mnjama (2004) and McLeod (2007) postulate that school management can make more efficient decisions with up-to-date Management Information System in place.

Management Information System of students ensures the efficient and effective management of university teaching and learning process (Palmer, 2000; Hounsome, 2001; Longe, 2001; Mutula, 2009). Management Information System is central to the administration of tertiary institutions in Ghana hence an effective and efficient Management Information System allow proper monitoring of students records (Cox, 2000; IMRT, 2008; Egwunyenga, 2009; Addo, 2010; Brendan, 2012; Ampofo, 2019).

The importance attached to MIS is expatiated by Kemoni (2000) who assertes that many years of neglect had done a great damage to the education sector in many developing countries. Also, Ezeani (2010) asserts that technical personnel who maintain the registry systems are inadequate in many developing countries. It has become a recurrent issue for student's information to be irretrievable when required especially in Ghanaian tertiary institutions of which University for Development Studies (Wa campus) is not an exception. According to Mrwebi (2000) and Otuama (2010) Management Information System (MIS) in many tertiary institutions in Africa is not working properly hence there are a lot of challenges encountered by students in accessing their information through the MIS.

\section{METHODOLOGY}

\section{Research Design}

This study used the descriptive survey design. Ampofo (2020) view descriptive survey as a design that portrays accurately the characteristic of particular individual situations or groups. According to Creswell (2013) and Ampofo (2020) a descriptive survey provides a quantitative or numeric description of trends, attitudes, or opinions of a population by studying a sample of that population. The descriptive survey was considered the most appropriate design for conducting this research because information gathered from the descriptive research can be meaningful or useful in diagnosing a situation since it involves describing, recording, analysing and interpreting conditions that exist (Ampofo, 2020). The descriptive survey was again considered the most appropriate design for conducting this study because it is the one that deals with things as they currently are (Ampofo, 2020). The researcher employed qualitative case study methodology to understand the challenges of UDS (Wa campus) students' Management Information System.

\section{Study Area}

The focus of this study is to find out the challenges students encountered in assessing UDS (Wa campus) Management Information System. The location for the study is UDS, Wa campus which is situated within the Wa Municipality of the Upper West Region of Ghana.

\section{Population}

The target populations for the study were students, teaching staff and management (nonteaching staff) of all faculties (Faculty of Planning and Land Management, Faculty of 
Integrated Development Studies and Faculty of Business) of the University for Development Studies, Wa campus.

\section{Sample Size}

According to Ampofo (2020) it is difficult to study a large population. As such a portion of the population can be studied purposive sampling was then employed to sample key participants such as senior and junior lecturers, administrators (examination officers, faculty officers and other administrative assistants) as well as student leaders for the study. The reason is that these key participants are in authority and would be in a better position to reveal the relevant information needed for the study. The study purposively selected twenty (20) student leaders from Faculty of Planning and Land Management, Faculty of Integrated Development Studies and Faculty of Business and Law, six (6) administrators and fourteen (14) senior and junior lecturers.

\section{Sampling Techniques}

Non-probability sampling techniques were used for the study. Thus purposive random sampling was employed to interview the key informants to carry out the study.

\section{Methods of Data Collection}

The sources from which the researchers intended to collect data were primary and secondary sources. Primary data were collected using interviews such as key informant interviews and participant observation. The main instruments used to collect field data was an interview guide. Secondary data, on the other hand, were sourced from journals, periodicals, newsletters and other documentary sources deemed relevant.

\section{Data Analysis}

Analysis of data provided facts that enabled interpretation of the results and to aid in the reaching of conclusions for the findings of the study. The interviews were recorded in audio and information received was later transcribed and analysed extensively through several readings. All the transcripts were then coded using the themes.

\section{RESULTS AND DISCUSSION OF RESULTS}

\section{Introduction}

Management Information Systems of student's records is in every university in Ghana but the reality of the student's Management Information System in Ghana especially that of UDS (Wa Campus) are always questionable. The study findings were in description without any values, figures, tables and charts.

\section{General Impression of UDS MIS}

Forty participants were interviewed for this research comprising of twenty (20) student leaders, six (6) administrators and fourteen (14) senior and junior lecturers. The participants were purposely selected. The participants were asked to express their opinions on students' Management Information System of UDS. From their responses, it is true that UDS have adopted Management Information System to keep the records of their students. Again, the respondents clearly stated that "student Management Information System provided greater satisfaction to the users compared with the existing system with regard to the delivery of enrolment procedures, registration of courses, checking of exams results and keeping of student information records."

This is in line with the study by Pali (2009) who asserted that record management is in existence in many tertiary institutions in Africa and this have evolved from a paper-based 
function to one concerned with the management of specific internal records in a multitude of media from creation to disposal through their active use as sources of information and ultimate review against retention schedules for their eventual distraction. This clearly shows that UDS (Wa campus) students' Management Information System is good when compared to the old manual system used by the University.

The transcript revealed that the usage of MIS by UDS has helped the University to work faster with regard to management of student's records. Many of the participants added and accepted that UDS (Wa campus) administrators, lecturers and students all can access to use the University MIS with their respective codes/passwords. Again one participant indicated that:

"UDS (Wa campus) students' Management Information System is good because it helps administrators and lecturers to work on student's records faster and also help students to assess their academic information without going through the rigorous process of letter writing to various department heads before they can assess their examination results."

Also, some of the participants expressed that:

"UDS is using MIS but still operating many at times operates manually on student's records especially during registration of courses at the beginning of every trimester.".

The general performance of the UDS (Wa campus) student's Management Information System was found to be "very bad" by respondents. The above statement clearly indicates that UDS (Wa campus) MIS is faced with a lot of challenges.

\section{Challenges of UDS Management Information System}

During our research work based on our interview that was conducted in relation to the topic, an assessment of student information system, UDS-Wa campus, the data was analysed in relation to the four major themes in the interview guide; background of participants, administrative challenges, students' challenges and lecturers' challenges.

\section{a. Administrator's challenges}

From the transcript, all the participants (administrators) interviewed expressed that students' Management Information System is a good system but they faced a lot of challenges in assessing the UDS (Wa campus) students' Management Information System at times. The participants stated that:

“The UDS (Wa campus) students' Management Information System is on average now because the networking is not fast and working on student's records at times corrupt because the database system they are using in Wa campus is not the original software and at times all their saved documents corrupt."

The assertion is consistent with the study Pember (2010) recommended that students' Management Information System must be operated by Information Communication Technology expert and be guided by proper maintenance, security, preservation of the content and context.

One of the participant also stated that:

"They are taking through some small training as administrators in assessing and managing the students' information system in Wa campus as such they do not know 
everything in the software which makes them slow in their work because they have to read every information on it very detail before using it to work on students' records".

It is also contrary to Blake (2014) assertion which states that records office staff should be trained to equip them with the necessary skills to carry out their functions properly.

Also one of the participants stated that:

"The students' MIS is very slow and at times students" records are distorted"

All the participants also expressed that:

'They do not understand the database system and is only one person from Tamale who managed and understood it and they expressed bitterly that such a person is not even a professional in ICT from accredited University but knows ICT small."

The aforesaid expressions by the participants clearly show that they encounter a lot of challenges with the students' MIS of University for Development Studies, Wa campus which was managed by the central administration in Tamale.

\section{b. Student's Challenges}

From the transcript, all the participants indicated that UDS (Wa campus) students' Management Information System was not working effectively. Most of the respondents expressed that:

“UDS (Wa campus) do not have a students' Management Information System officer in general so whenever they want some important information they are told to go to Tamale."

This make students go through a lot of stress before getting their information. This is inconsistent with Ezeani (2010) assertion that for a sound students' Management Information System practices to take place, heads of institutions should designate or appoint a Management Information System manager who will develop and implement records management policies endorsed by the head of the organisation and the top management team.

Most of the participants expressed that logging into their student user account became a challenge to them at times because the system always showed that their password was incorrect whiles they had entered the correct password. Again most of the participants stated that:

"When it comes to Management Information System UDS (Wa campus) is not having the expertise to do that so is better to go through the manual system."

The participants indicated that whenever they logged into the student's portal to check their results nothing was there whiles results had been posted on the notice board by school administrators. This statement was angrily expressed by the participants. In addition, most of the participants stated that the students' Management Information System of the UDS (Wa campus) was too slow as such wasted their time anytime they wanted to assess their information. One of the participants stated that, "before you can log into the student's 
information system as a student you have to go through a lot of procedures and steps which are so tedious and boring unlike other universities you just log in with your student ID and secret password without any long process?"

Participant 2 stated that:

"The database of the students' Management Information System is always corrupted and at times some students do not trail for a course but whenever they check their results online they have failed so that makes them so disturbed". In addition, all the participants clearly indicated that the University Students' Management Information System is in a poor state since the system is ineffective always showing error.

Again one of the participants stated that, "at times when students enter their details into the Management Information System different person picture and details is there." This makes students go through a lot of processes for it to be corrected and this makes students psychologically unsound in mind to concentrate on their academic work. In all, the general challenges students encountered whenever they assess UDS (Wa campus) is the delay of the process of the software and wrong password notification on their student's portal as expressed by the participants.

\section{c. Lecturer's Challenges}

From the transcript, all the lecturers interviewed stated that they had challenges any time they accessed the UDS (Wa Campus) MIS. For example, the participants added and accepted that the students' Management Information System of the University for Development Studies, Wa campus is very slow with so many errors. For instance, Participant 1 stated: 4

"That when he accesses the portal and enters students results after completion the system cannot save and all that he entered are corrupted so he always sends it to the examination office for them to do entry for him".

Again, from the transcripts, all participants were faced with a lack of training on how to use the students' Management Information System well which made them very difficult to use the students' Management Information System. This is what all the interviewers had to say:

"I have never been successful and have full command and control in using the University Students' Management Information System”.

With this, it becomes difficult for lectures to use the online system but rather prefer the manual way and this makes the lecturers not to be technologically inclined with information communication technology.

This is what all the participants actually said about their usage of UDS, Wa campus MIS:

"The University Management Information System makes it very difficult for lecturers to track student's records due to its nature of distorting and corrupted database." Participant 1 stated that: "At times when he logs into his account the database indicated wrong password and cannot assess his information. He angrily stated that, 
"if lecturers cannot assess their information and records then what about mere students."

This shows that lecturers of University for Development Studies, Wa campus is having a lot of challenges as stated by all the participants.

\section{Improving Students Management Information System (MIS)}

Information management system of UDS (Wa campus) according to the participants needs a lot of improvement. Most of the participants stated that, "if the Management Information System is improved it will be very good." The following are the participant's views on how to improve UDS (Wa campus) students' Management Information System.

\section{a. Students Views on how to Improve UDS Management Information System}

All the student participants expressed that for the University Management Information System to function effectively, "management of UDS should consider the student MIS as a priority. Management should take a good look at it and analyse what brought about challenges and find possible alternatives to overcome those challenges." All the student participants also stated that, "management should employ experts in MIS to handle the students' Management Information System and also the University should employ ICT experts and individuals who are willing and can be able to work hard to make the overall UDS MIS effectively and efficiently but not any ordinary personnel.

\section{b. Administrators and Lecturers Views on how to Improve UDS Management Information System}

The entire participants (administrators and lecturers) interviewed indicated clearly that the University Management Information System needs an improvement. One of the participants stated that every department and faculties should have an expert in Management Information System to work there alongside normal school administrative workers. All the participants stated that, "UDS (Wa campus) needs an expert to manage the Management Information System thereby training all stakeholders such as administrators, lecturers and the entire students on how to use the Management Information System portal.

Again one of the participants stated that, "the university authorities should buy the correct database system rather than cheap ones which later brings a lot of problems." All the participants stated that UDS (Wa campus) was the largest among all the UDS campuses in terms of population as such they should have an information management system office with ICT specialist to deal with only Management Information System and if this is established, the university performance will increase.

It was also made known that without an efficient and effective Management Information System by UDS, the most applicant into the university will stop and go to other universities because their siblings in the university will tell them the challenges of the Management Information System as such the participants stated that the university authority must seriously employ qualified personnel to do the work rather than employing their natives who did not know anything about Management Information System and ICT. 


\section{SUMMARY OF MAJOR FINDINGS}

The study revealed that UDS, Wa campus Management Information System is in existence. All the participants interviewed recognised the importance of the students' Management Information System. For instance, majority of the participants expressed that Management Information System had made the University for Development Studies (Wa campus) to record students' academic information very fast. Again, the study revealed that UDS (Wa campus) Management Information System has made the university upgraded itself in ICT. It was also explicitly made known that the UDS (Wa campus) Management Information System are faced with a lot of challenges.

All the participants stated clearly that the university students' Management Information System is having a lot of challenges. Findings show that most students are unable to assess the Management Information System regardless of entering their correct student's identification number and password. Also, findings show that the web page and database of the Management Information System are slow and are distorted always. Even the university administrators and lectures at times are not able to assess the Management Information System to carry on their activities thereby ensuring quality education delivery.

Findings also show that UDS (Wa-campus) does not have a Management Information System manager but rather depends on the manager at Tamale campus for its operations. Therefore, the workers operating the Management Information System in UDS (Wa campus) are not the main controller or developer of the Management Information System as compared to other public universities of the country who have their own MIS experts. Findings also show that students and lecturers at times are not able to log into the system due to disruption of the database system. Findings show that UDS (Wa campus) students' Management Information System is on average now because the networking is not fast and working on student's records at times corrupt.

Findings also show that administrators of the UDS (Wa campus) Management Information System are not taking through proper training in using the system. Findings also show that UDS (Wa campus) depend on only one manager of the student's information system at Tamale who always come to Wa to rectify problems of the database whenever the system corrupt or jammed. The study further discovered that as far as students' Management Information System is concerned there are individuals who are in-charge within the various departments and faculties in the university. None of the respondents stated that they have a students' information system manager or any other appointed officer who controls the system. The study indicated that the most serious challenges associated with the Management Information System of University for Development Studies, Wa campus is inadequate professionally trained Management Information System operators.

\section{CONCLUSIONS}

From the study, it can be deduced that students' Management Information System are inextricably entwined with increased the UDS performance in terms of students' academic information management. It also became apparent that unqualified personnel are working on the Management Information System in UDS (Wa campus) and also the university lacked qualified professionals to manage its students' Management Information System.

UDS (Wa campus) students' Management Information System should, therefore, be managed in the same manner as other universities in Ghana do. The study further revealed that UDS 
students' Management Information System is not reliable, very slow and always disrupts activities of the users.

\section{Recommendations}

From the findings of the study, it is evident that administrators, lecturers and students of University for Development Studies (UDS), Wa campus used Management Information System. Students used it to check their academic information, lectures used it to work on students' information such as exercises, mid-trimester quizzes and final examination results and also administrators used it for administrative activities and management of students' academic information.

The study recommends that UDS, Wa campus currently an autonomous university now called Simon Diedon Dombo University of Business and Integrated Development Studies should incorporate strategic planning initiatives to adopt a proper Management Information System managed by Information and Communication Technology expert in the field of Management Information System or Computer Engineering. Again, the study recommends that Management Information System operators of University for Development Studies (Wa campus) now an autonomous university called Simon Diedon Dombo University of Business and Integrated Development Studies should put a strong security architecture to avoid hacking into their Management Information System.

The study further recommends that University for Development Studies (Wa campus) senior management should embrace the Management Information System of students in the school so as to achieve high performance management targets. Finally, the study recommends that there should be workshop or training for teaching and non-teaching staffs and students of University for Development Studies, Wa campus now called Simon Diedon Dombo University of Business and Integrated Development Studies in the Wa Municipality of the Upper West Region of Ghana.

\section{Acknowledgements}

The researcher wants to thank the editorial board of Fair East Publishers, and also Antwi Abrefi Abigail (Law student at University of Professional Studies, Accra, Ghana) for her sound support and excellent contributions.

\section{Conflict of Interest Statement}

No conflict of interest has been declared by the author.

\section{Funding}

The researcher has not received any support for the publication of this paper.

\section{References}

Addo, P.K. (2010). The Contribution of Higher Education in National Development. International Journal of Educational Leadership, 2(2), 81-87.

Ampofo, A. J. (2020). Rural housing challenges in the Upper West Region of Ghana: A case study of Kulmasa. International Journal of Management \& Entrepreneurship Research, 2(4), 194-211. 
Ampofo, A. J. (2020). Waste disposal management practices in selected senior high schools within the Wa Municipality of Ghana. International Journal of Management \& Entrepreneurship Research, 2(4), 273-290.

Ampofo, A. J. (2020). The nature of mortgage repayment plans in Ghana. Finance \& Accounting Research Journal, 2(3), 91-104.

Ampofo, A. J (2020). Contributions of the hospitality industry (hotels) in the development of Wa. International Journal of Advanced Economics, 2(2), 21-38.

Ampofo, A. J. (2020). Implications of poor waste disposal management practices on senior high schools within the Wa Municipality of Ghana. International Journal of Applied Research in Social Sciences, 2(3), 53-70.

Ampofo, A. J. (2019). Performance management and appraisal in improving teachers quality: Lambert Academic Publishing.

Arora, S.P. (2006). Office Organization and Management. Vikas Publishing House London Pvt. Ltd, New Delhi.

Atulomuah, B., C. (2011). Perceived records management decision making among university administrators in Nigeria. Library Philosophy and Practice (e-journal). Paper 541

Azman M.I. (2009). Records Management and the Accountability of Governance (PhD Thesis), University of Glasgow, UK.

Blake, R. (2014). Benefits of Records Management. Retrieved January 2014, from: http://www.dummies.com/how-to/content/benefits-of-records-management.html

Brendan, E., \& Asogwa, (2012). The challenge of managing electronic records in developing countries: Implications for records managers in sub Saharan Africa. Records Management Journal, 22(3), 198 - 211.

Cowling, C. (2003). Records management manual. London: University of London.

Cox, R.J. (2001). Managing records as evidence information. London Westport.

Cresswell, J. W. (2013). Research Design. Qualitative, quantitative and mixed method approach. London, LO: Sage Publications Inc.

Egwunyenga, E.J. (2009). Records keeping in universities: associated problems and management options in South West geographical zone of Nigeria. International Journal of Education and Science, 1(2), 109-13.

Ezeani, C. (2010). "Information and communication technology: an overview", In Madu, E.C. and Ezeani, C.N. (Eds.), Modern Library and Information Science for Professionals in Africa, Text Kinks, Ibadan, pp. 7-29.

Hounsome, C. (2001). The records management challenges of amalgamation. Municipal Monitor, June/July: 1-7.

International Records Management Trust (IRMT), (2008). Integrating records management in ICT system: good practice indicator. IRMT, London.

Iwhiwhu, E, B. (2005). Management of Records in Nigerian Universities: Problems and Prospects. The Journal of Electronic Library, 23(3), 345-355.

Johare, R. (2001). Electronic records management in Malaysia: the need for an organizational and legal framework. Records Management Journal, 11(2), 97-109.

Kemoni, H., \& Wamukoya, J.S. (2000). Preparing for the management of electronic records at Moi University, Kenya: a case study. African Journal of Library, Archives \& Information Science, 10(2), 125-38. 
Longe, R.S. (2001). Introduction of Educational Planning. Seminar paper of the Educational planning Unit. Department of Educational management, University of Ibadan. Managing the public service strategies for improvement series: No. 6. March 1997, Atlanta, Georgia, U. S. A., pp 335-342.

McLeod, J., \& Childs, S. (2007). Records management capacity and compliance toolkits. Records Management Journal, 17(3), 216-232.

Mnjama, N. (2004). Records and information: the neglected resource. ESARBICA Journal 23, 44-59.

Mrwebi, S. (2000). Records management in a management consulting firm. Masters in Information Science. Johannesburg: Rand Afrikaans University.

Mutula, S., \& Wamukoya, J. (2009). Public sector information management in east and southern Africa: implications for FOI, democracy and integrity in government. International Journal of Information Management, 29, 333-341.

Otuama S. (2010). Problems Faced in Archives and Records Management in Kenya. http://informationscienceblog.blogspot.com/2010/06/problems-faced-in-archives andrecords.html

Pali. (2009). Records Management. Retrieved January 2014, from the World Wide Web:http://information-field.blogspot.com/2009/06/challenges-in-managingrecordcentre.html

Palmer, M. (2000). Records management and accountability versus corruption, fraud and maladministration. Records Management Journal, 10(2), 61-72.

Shepherd, E., \& Yeo, G. (2003). Managing records: a handbook for principles and practices. Facet Publishing, London.

Sing, T. F. (2002). Impact of Information \& Communication Technology (ICT) on Office Demand in Singapore CBD, Presentation to Association for Project Management APM). 